\title{
The removal of $\mathbf{N}$ and $\mathbf{P}$ in aerobic and anoxic-aerobic digestion of waste activated sludge from biological nutrient removal systems
}

\author{
M Vogts ${ }^{2}$, DS Ikumi' and GA Ekama'* \\ 'Water Research Group, Dept of Civil Engineering, University of Cape Town, Rondebosch, 7701, South Africa \\ ${ }^{2}$ Royal HaskoningDHV, Pietermaritzburg, South Africa
}

\begin{abstract}
Biological nutrient removal (BNR) activated sludge (AS) systems produce a waste activated sludge (WAS) that is rich in nitrogen (N) and phosphorus (P). When this sludge is thickened to 3-6\% total suspended solids (TSS) and digested (aerobic or anaerobic), a high proportion of $\mathrm{N}$ and $\mathrm{P}$ are released to the bulk liquid resulting in high concentrations of ammonia/nitrate and orthophosphate up to several hundred $\mathrm{mg} / \ell$ (without denitrification or P precipitation). This research investigates P removal by P precipitation in anoxic-aerobic digestion of P-rich BNR system WAS. The experimental setup for this work was a lab-scale membrane UCT BNR system fed real settled sewage with added acetate, orthophosphate, and cations $\mathrm{Mg}$ and $\mathrm{K}$ to increase biological excess $\mathrm{P}$ removal. This WAS was fed to batch aerobic digesters at various TSS concentrations, and to two 20-day retention time continuous anoxic-aerobic digesters (AnAerDig) with aeration cycles of 3-h air on and 3-h air off, one fed concentrated WAS (20 g TSS/ / ) and the other fed diluted WAS (3 g TSS/ $/$ ). Nitrogen removal has been discussed in the previous paper. This paper focuses on the P removal by P precipitation observed in the batch tests and continuous systems. The rate of polyphosphate release $\left(b_{\mathrm{GP}}\right)$ during batch aerobic digestion at low TSS without $P$ precipitation was found to be 2.5 times faster than the endogenous respiration rate $\left(b_{C}\right)$ of phosphorus accumulating organics $(\mathrm{PAO})$, i.e. $b_{\mathrm{GP}}=0.1 / \mathrm{d}$. This rate was then applied to the high-TSS aerobic batch tests and continuous anoxic-aerobic digesters to estimate the $\mathrm{P}$ precipitation at various TSS concentrations, with and without additional $\mathrm{Mg}$ or $\mathrm{Ca}$ dosing. Newberyite $\left(\mathrm{MgHPO}_{4} \cdot 3 \mathrm{H}_{2} \mathrm{O}\right)$ and amorphous tricalcium phosphate $\left(\mathrm{ACP}\right.$ or TCP, $\left.\mathrm{Ca}_{3}\left(\mathrm{PO}_{4}\right)_{2} \cdot \mathrm{xH}_{2} \mathrm{O}\right)$ are found to be the most common phosphate precipitates.
\end{abstract}

Keywords: biological excess phosphorus removal, waste activated sludge, anoxic-aerobic digestion, phosphate release, mineral precipitation.

\section{INTRODUCTION}

The release rate of polyphosphate from nitrification-denitrification biological excess phosphorus removal (NDBEPR) waste activated sludge (WAS) in anaerobic and aerobic digesters has been studied by the Water Research Group at the University of Cape Town for the past 8 years. In anaerobic digestion, the release of polyphosphate was found to be complete within 5 days of digestion (Harding, 2009), due to the availability of acetate under anaerobic conditions, followed by a slower $\mathrm{P}$ release as the organics of the biomass (phosphate-accumulating organisms, PAO and ordinary heterotrophic organisms, $\mathrm{OHO}$ ) is digested. In aerobic digestion, it was previously accepted that the PAO polyphosphate was released at the same rate as the $\mathrm{PAO}$ endogenous respiration rate, $\mathrm{b}_{\mathrm{G}}$ (Mebrahtu and Ekama, 2008; Mebrahtu et al., 2010). In this paper, the rate of polyphosphate release is shown to be 2.5 times faster than $b_{\mathrm{G}}$; it is completely released in about 15 days in aerobic batch digestion.

A high P removal UCT NDBEPR system was operated to provide the P-rich WAS for this study. This WAS was used to start aerobic batch digestion tests at different total suspended solids (TSS) concentrations to observe the N and
$\mathrm{P}$ release, and the WAS was also fed to 2 continuously-fed (once daily) anoxic-aerobic digesters operated at a steadystate sludge age of $20 \mathrm{~d}$ at high $(20 \mathrm{~g}$ TSS $/ \ell)$ and low $(3 \mathrm{~g}$ TSS/ $\ell$ ) TSS concentrations. Moreover, the anoxic-aerobic digested (effluent) sludge waste was further digested in batch aerobic digesters, to check for further P release and denitrification capabilities.

To determine and quantify which phosphate minerals precipitate, weak acid/base chemistry principles (Loewenthal et al., 1994) were applied to the actual and predicted dewatering liquor (DWL) aqueous phases. Interestingly, struvite was found not to precipitate, most likely due to the complete nitrification of ammonia released in digestion.

\section{METHODOLOGY}

To observe the rate of release of polyphosphate from P-rich WAS, a lab-scale UCT system was set up with membranes for solid-liquid separation. This NDBEPR system was operated for enhanced bio-P removal with acetate $(200 \mathrm{mg} \mathrm{COD} / \ell$ influent), $\mathrm{Mg}$ and $\mathrm{K}$ added to its settled sewage feed (see Vogts and Ekama, 2012, for details). A summary of this system's operating conditions is given in Table 1 .

This paper was originally presented at the 2014 Water Institute of Southern Africa (WISA) Biennial Conference, Mbombela, 25-29 May 2014.

* To whom all correspondence should be addressed.

욜 +27 21650 2585; e-mail: george.ekama@uct.ac.za 
TABLE 1

Operating conditions of the lab-scale NDBEPR system

\begin{tabular}{|c|c|}
\hline Parameter & UCT NDBEPR \\
\hline Influent flow $(\ell / \mathrm{d})$ & 150 \\
\hline 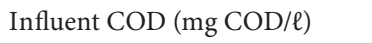 & $\sim 800$ \\
\hline Influent TKN (mg TKN-N/l) & $45-65$ \\
\hline Influent Total P (mg TP-P/l) & $45-60$ \\
\hline Aerobic-anoxic recycle ratio & 2.8 \\
\hline Anoxic-anaerobic recycle ratio & 1.31 \\
\hline Anaerobic reactor volume $(\ell)$ & 19 \\
\hline Anoxic reactor volume $(\ell)$ & 21 \\
\hline Aerobic reactor volume $(\ell)$ & 35 \\
\hline $\begin{array}{l}\text { Anaerobic mass/volume } \\
\text { fractions }\end{array}$ & $0.136 / 0.253$ \\
\hline Anoxic mass/volume fractions & $0.265 / 0.280$ \\
\hline Aerobic mass/volume fractions & $0.599 / 0.467$ \\
\hline Waste flow from aerobic $(\ell / d)$ & 5.7 \\
\hline Sludge age $(\mathrm{d})$ & $10-11$ \\
\hline 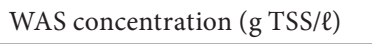 & $8-10$ \\
\hline$f_{\mathrm{P}} \mathrm{WAS}(\mathrm{mg} \mathrm{P} / \mathrm{mg} \mathrm{VSS})$ & $0.1-0.14$ \\
\hline$f_{\mathrm{i}}$ WAS (mg VSS/mg TSS) & $0.65-0.7$ \\
\hline
\end{tabular}

TKN: total Kjeldahl nitrogen

COD: chemical oxygen demand

VSS: volatile suspended solids
The WAS withdrawn from the aerobic reactor of this UCT system (Ekama, 2010) was concentrated (8-10 g TSS/ $\ell$ ) due to the membranes (Ramphao et al., 2005) and high in P (0.10$0.14 \mathrm{mg} \mathrm{P} / \mathrm{mg}$ VSS). The UCT system also effectively removed $\mathrm{N}$, having an effluent (and WAS stream) with low ammonia (1-3 $\left.\mathrm{mg} \mathrm{NH}_{4}-\mathrm{N} / \ell\right)$ and nitrate below effluent quality standards $(8-15 \mathrm{mg} \mathrm{NO}-\mathrm{N} / \ell)$. The effluent orthophosphate was high (15-25 $\mathrm{mg} \mathrm{PO}_{4}-\mathrm{P} / \mathrm{l}$ ) due to the $\mathrm{P}$ (and $\mathrm{Mg}$ and $\mathrm{K}$ ) dosed to the influent. Consequently, $\mathrm{P}$ was not limiting and therefore maximised the P content of the WAS. The P-rich WAS was batch digested at low and high TSS to observe the rate of $\mathrm{P}$ release and extent of $\mathrm{P}$ precipitation, and also fed to 2 continuously fed (once daily) anoxic-aerobic digesters: one was fed concentrated WAS $(2 \times)$ at $20 \mathrm{~g}$ TSS/ $\ell$ and the other was fed dilute WAS (1/3) at $3 \mathrm{~g}$ TSS/ $\ell$ as described in Vogts and Ekama (2012). The plant-wide layout of the UCT system and linked anoxic-aerobic digesters are shown in Fig. 1.

Sewage batches were collected from Mitchell's Plain wastewater treatment plant (Cape Town, South Africa) in 2 $000 \ell$ batches, macerated and stored in $400-\ell$ stainless steel tanks in a $4^{\circ} \mathrm{C}$ cold room. These sewage batches were numbered sequentially, and fed in turn to the UCT system, each batch lasting a period of about 3 weeks. The results, measured on the influent, reactors and effluent of the UCT system, were averaged over a sewage batch period to give the average performance of the system for that period.

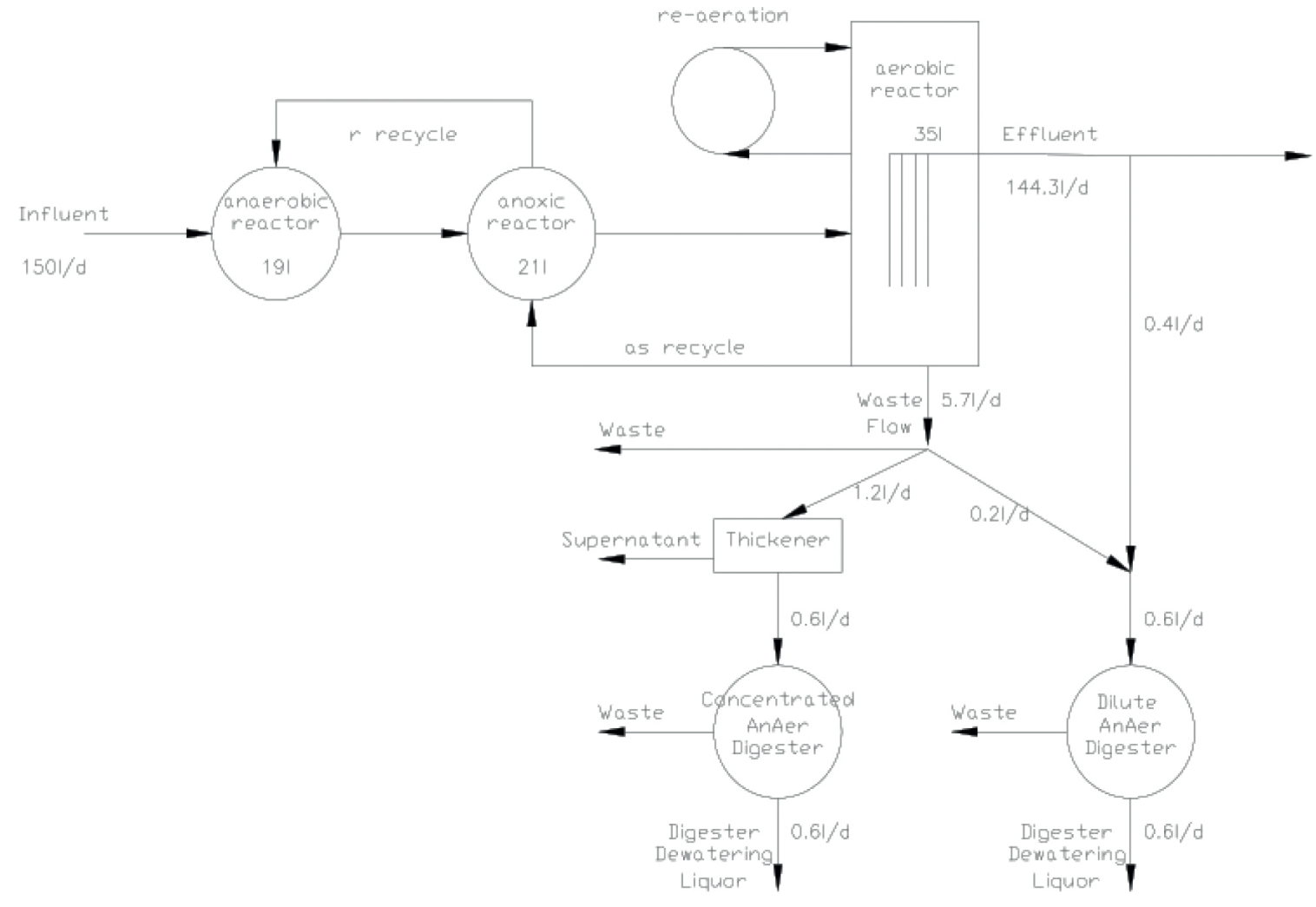

Figure 1

Layout of UCT MBR NDBEPR system and linked anoxic-aerobic digesters (AnAerD) operated for 2 years (2009-2010), for the study of N and P removal in AnAerD of NDBEPR WAS. 
From January 2008 to October 2010, the 2 anoxic-aerobic digesters were operated over 4 time periods, each with different dosing chemicals for P precipitation and 2 different aeration patterns as shown in Table 2 . This was to observe the effect of $\mathrm{pH}$ on nitrification and $\mathrm{P}$ precipitation, the effect of different cations on $\mathrm{P}$ precipitation and the build-up of nitrate under fully aerobic conditions at 20 -days retention time to monitor the biomass digestion rate via the nitrate increase. Table 3 gives the quantities of additives dosed to the WAS feed of each digester during the 4 time periods. Alkalinity was added to maintain a $\mathrm{pH}$ between 7.2 and 7.5. Average results for both digesters over the 4 time periods, as well as the impact of continuous aeration on the low-TSS digester's oxygen uptake rate (OUR) and the impact of added $\mathrm{Mg}$ and Ca on the high-TSS digester's orthophosphate and filtered polyphosphate cations were presented in Vogts and Ekama (2012). Full results of the investigation are given in Vogts et al. (2014).

\section{Aqueous-solid phase weak acid base chemistry}

Batstone et al. (2012) discuss the importance of ionic interactions (weak acid-base chemistry) in wastewater treatment modelling. These interactions affect the alkalinity and $\mathrm{pH}$ of a solution.

Weak acid-base chemistry involves the processes of solid-aqueous liquid (and aqueous-gas) interaction, as when at high enough aqueous cation and anion concentration, minerals precipitate to become solid. The cations and anions involved with aerobic digestion are the trivalent phosphate system, divalent carbonate (as carbon dioxide is produced, dissolves and some exits the system by air stripping), ammonia, nitrate and metal cations. This mix of weak and strong acids and bases at different concentrations is evaluated to check if phosphate precipitates with metal cations and ammonia. These processes are well described by Loewenthal et al. (1994) and Harding (2009) for determining ionic products of the different cations and anions that make up various minerals in anaerobic digester dewatering liquor. These same principles are applied to the aqueous phase aerobic and anoxic-aerobic digestion at high and low TSS concentrations.

TABLE 2

The four anoxic-aerobic digester investigation periods

\begin{tabular}{|c|l|c|c|c|c|l|l|}
\hline \multirow{2}{*}{ Period } & \multicolumn{1}{|c|}{ Dates } & \multicolumn{3}{|c|}{ High-TSS digester } & \multicolumn{3}{c|}{ Low-TSS digester } \\
\cline { 2 - 8 } & \multicolumn{1}{|c|}{ Days } & Aeration & \multicolumn{1}{c|}{ Dosing } & Days & \multicolumn{1}{c|}{ Aeration } & \multicolumn{1}{c|}{ Dosing } \\
\hline 1 & 24 Jan 2008 -25 May 2009 & 484 & Intermittent $^{\mathrm{a}}$ & None & 96 & Intermittent & None \\
\hline 2 & 26 May 2009-25 Jan 2010 & 245 & Intermittent & $\mathrm{NaHCO}_{3}$ & 245 & Intermittent & $\mathrm{NaHCO}_{3}$ \\
\hline 3 & 26 Jan 2010-19 July 2010 & 175 & Intermittent & $\mathrm{Mg}(\mathrm{OH})_{2}$ & 175 & Continuous & $\mathrm{NaOH}$ \\
\hline 4 & 20 July 2010-20 Oct 2010 & 93 & Intermittent & $\mathrm{Ca}(\mathrm{OH})_{2}$ & 93 & Continuous & $\mathrm{NaOH}$ \\
\hline
\end{tabular}

a $3 \mathrm{~h}$ aeration on, followed by $3 \mathrm{~h}$ aeration off for all intermittent aeration cycles

${ }^{\mathrm{b}}$ The low-TSS digester was started on 18 February 2009. The results collected from the high-TSS digester during 2008 were presented in Vogts and Ekama (2012).

\begin{tabular}{|c|c|c|c|c|c|c|c|c|}
\hline \multicolumn{9}{|c|}{$\begin{array}{l}\text { TABLE } 3 \\
\text { Dosages to the WAS feed of the anoxic-aerobic digesters during their 2-year operation }\end{array}$} \\
\hline \multirow{3}{*}{ Period } & \multirow{3}{*}{$\begin{array}{c}\text { Sewage } \\
\text { batch }\end{array}$} & \multicolumn{7}{|c|}{$\begin{array}{ll}\text { High-TSS digester } \\
\end{array}$} \\
\hline & & \multirow[b]{2}{*}{ Alk added } & Conc & Amount & Alk (mg/d & \multirow{2}{*}{$\begin{array}{l}\text { Cation } \\
\text { added }\end{array}$} & Conc & Amount \\
\hline & & & $g / \ell$ & $\mathrm{m} \boldsymbol{\ell}$ & $\left.\mathrm{CaCO}_{3}\right)$ & & $\mathrm{g} / \ell$ & $m \boldsymbol{l}$ \\
\hline 1 & 1 to 3 & \multicolumn{4}{|c|}{ None } & \multicolumn{3}{|c|}{ None } \\
\hline 2 & 4 to 11 & $\mathrm{NaHCO}_{3}$ & 40 & 10 & 240 & \multicolumn{3}{|c|}{ None } \\
\hline $3 \mathbf{a}$ & 12 to 13 & $\mathrm{NaOH}$ & 19.1 & 15 & 710 & $\mathrm{Mg}$ & 48 & 10 \\
\hline $3 b$ & 14 to 17 & $\mathrm{NaOH}$ & 38.1 & 20 & 950 & $\mathrm{Mg}$ & 97 & 10 \\
\hline $4 a$ & 18 to 20 & $\mathrm{NaOH}$ & 38.1 & 35 & 1670 & $\mathrm{Ca}$ & 70 & 50 \\
\hline $4 b$ & 21 & $\mathrm{NaOH}$ & 38.1 & 15 & 715 & \multicolumn{3}{|c|}{ None } \\
\hline
\end{tabular}

\begin{tabular}{|c|c|c|c|c|c|c|c|c|}
\hline \multirow{3}{*}{ Period } & \multirow{3}{*}{$\begin{array}{c}\text { Sewage } \\
\text { batch }\end{array}$} & \multicolumn{7}{|c|}{ Low-TSS digester } \\
\hline & & \multirow[b]{2}{*}{ Alk added } & Conc & Amount & Alk (mg/d & \multirow{2}{*}{$\begin{array}{l}\text { Cation } \\
\text { added }\end{array}$} & \multirow{2}{*}{$\begin{array}{c}\text { Conc } \\
g / \ell\end{array}$} & \multirow{2}{*}{$\frac{\text { Amount }}{\mathrm{m} \ell}$} \\
\hline & & & $\mathrm{g} / \ell$ & $m \ell$ & $\left.\mathrm{CaCO}_{3}\right)$ & & & \\
\hline 1 & 1 to 3 & \multicolumn{4}{|c|}{ None } & \multicolumn{3}{|c|}{ None } \\
\hline 2 & 4 to 11 & $\mathrm{NaHCO}_{3}$ & 40 & 5 & 119 & \multicolumn{3}{|c|}{ None } \\
\hline 3 & 12 to 13 & $\mathrm{NaOH}$ & 19.1 & 5 & 119 & $\mathrm{Mg}$ & 48.41 & 5 \\
\hline 3 & 14 to 17 & $\mathrm{NaOH}$ & 38.1 & 5 & 238 & \multicolumn{3}{|c|}{ None, fully aerobic } \\
\hline 4 & 18 to 21 & $\mathrm{NaOH}$ & 38.1 & 7 & 333 & \multicolumn{3}{|c|}{ None, fully aerobic } \\
\hline
\end{tabular}

Note: $\mathrm{Mg}\left(\mathrm{MgCl}_{2} \cdot 6 \mathrm{H}_{2} 0 \mathrm{M}=203.3 \mathrm{~g} / \mathrm{mol}\right)$ and $\mathrm{Ca}\left(\mathrm{CaCl}_{2} \cdot 2 \mathrm{H}_{2} \mathrm{O} \mathrm{M}=147.2 \mathrm{~g} / \mathrm{mol}\right)$ 
Loewenthal et al. $(1989,1991)$ and Harding (2009) developed a method whereby a solution containing many dissolved species can be characterised in its weak acid base systems. This is useful for dosing (e.g. to precipitate a certain amount of phosphate by dosing lime). Here the digester aqueous phase (which becomes dewatering liquor after solid-liquid separation) is characterised to assess what phosphate minerals potentially precipitate.

The weak acid base species involved in aerobic digestion and their dissociation equations and constants (pKs) from Loewenthal et al. (1991) are given below. Trivalent orthophosphate (released from organics and polyphosphate), divalent carbonate from dissolved carbon dioxide and monovalent ammonia dissociate as follows:

$$
\begin{aligned}
& K_{p 1}=\frac{\left[\mathrm{H}^{+}\right]\left[\mathrm{H}_{2} \mathrm{PO}_{4}^{-}\right]}{\left[\mathrm{H}_{3} \mathrm{PO}_{4}\right]}, K_{p 2}=\frac{\left[\mathrm{H}^{+}\right]\left[\mathrm{HPO}_{4}^{2-}\right]}{\left[\mathrm{H}_{2} \mathrm{PO}_{4}^{-}\right]} \text {and } K_{p 3}=\frac{\left[\mathrm{H}^{+}\right]\left[\mathrm{HPO}_{4}^{2-}\right]}{\left[\mathrm{HPO}_{4}^{2-}\right]} \\
& K_{c 1}=\frac{\left[\mathrm{H}_{3}^{+}\right]\left[\mathrm{HCO}_{3}^{-}\right]}{\left[\mathrm{H}_{2} \mathrm{CO}_{3}\right]} \text { and } K_{c 2}=\frac{\left[\mathrm{H}^{+}\right]\left[\mathrm{HCO}_{3}^{2-}\right]}{\left[\mathrm{H}_{2} \mathrm{CO}_{3}^{-}\right]} \\
& K_{a 1}=\frac{\left[\mathrm{H}^{+}\right]\left[\mathrm{NH}_{3}\right]}{\left[\mathrm{NH}_{4}^{+}\right]}
\end{aligned}
$$

Nitrate is a strong acid and so, like the metal cations $\left(\mathrm{K}^{+}, \mathrm{Mg}^{2+}\right.$ and $\mathrm{Ca}^{2+}$ ), is completely dissociated. Nitrate is only in dissolved form and so can only be measured in soluble form, but the cations can be in solid or dissolved forms and were measured in filtered and unfiltered samples.

The dissociation Eqs (1) to (3) need to be corrected for activity, for example for the phosphate subsystem:

$$
\begin{aligned}
& K_{p 1}^{\prime}=\frac{\left(\mathrm{H}^{+}\right)\left[\mathrm{H}_{3} \mathrm{PO}_{4}^{-}\right]}{\left[\mathrm{H}_{3} \mathrm{PO}_{4}\right]}=\frac{K_{p 1}}{f_{m}}, K_{p 2}^{\prime}=\frac{\left(\mathrm{H}^{+}\right)\left[\mathrm{HPO}_{4}^{2-}\right]}{\left[\mathrm{H}_{3} \mathrm{PO}_{4}^{-}\right]}=\frac{f_{m}}{K_{p 2}} f_{d} \text { and } \\
& K_{p 3}^{\prime}=\frac{\left(\mathrm{H}^{+}\right)\left[\mathrm{HPO}_{4}^{2-}\right]}{\left[\mathrm{HPO}_{4}^{2-}\right]}=\frac{f_{1} K_{p 3}}{f_{1}}
\end{aligned}
$$

where ( ) denotes activity $\mathrm{mol} / \ell$ and [ ] mass $\mathrm{mol} / \ell$. The activity is calculated as follows: with reference to the most protonated species: $f_{m}$ for one proton away (monovalent), $f_{d}$ two (divalent) and $f_{t}$ three protons away (trivalent), e.g., $\mathrm{PO}_{4}^{3-}$ has lost 3 protons from its most protonated form, $\mathrm{H}_{3} \mathrm{PO}_{4}$. The activities of ions depend on the aqueous ionic strength, or conductivity, which is more accurately measured than TDS (total dissolved solids), viz.

$$
\log f_{1}=A z_{1}^{2}\left(\frac{\mu^{1 / 2}}{\mu^{1 / 2}+1}-0.3 \mu\right)
$$

where:

$f_{\mathrm{i}}$ is the activity coefficient for ionic species $\mathrm{i}$, written as $f_{m}$, $f_{\mathrm{d}}$ and $f_{t}$ for mono-, di- and trivalent ions, respectively

$\mu$ is ionic strength $=1.68^{*} 10^{-4 *} \mathrm{SC}$ where SC is the measured specific conductance $(\mathrm{mS} / \mathrm{m})$

$Z_{i}$ is the charge of the $i^{\text {th }}$ species, 1 for mono-, 2 for di- and 3 for trivalent
$A$ is a temperature-dependent constant $=1.825^{\star} 10^{-6}(78.3 \mathrm{~T})^{-1.5}$ with $\mathrm{T}$ in Kelvin

$\mathrm{pH}$ is directly measured as activity, i.e.,

$$
\left(\mathrm{H}^{+}\right)=10^{-p H}
$$

where $\left(\mathrm{H}^{+}\right)$is the measured $\mathrm{pH}$, i.e. $\mathrm{pH}=-\log \left(\mathrm{H}^{+}\right)$

Therefore, for example, the mass concentration of aqueous $\mathrm{PO}_{4}^{3-}$ can be found from inserting the species' $p K s$ in Eq. (4) into the total phosphate $\left(P_{\mathrm{T}}\right)$ equation $P_{\mathrm{T}}=\left[\mathrm{H}_{3} \mathrm{PO}_{4}\right]+\left[\mathrm{H}_{2} \mathrm{PO}_{4}\right]$ $+\left[\mathrm{HPO}_{4}^{2-}\right]+\left[\mathrm{PO}_{4}^{3-}\right]$, rearranging to find $\left[\mathrm{PO}_{4}^{3-}\right]$, and inserting activities.

To judge the precipitation potential of a possible precipitant, the ionic product (multiplication of the involved ionic species) is found and compared with its solubility product. Of particular interest here is phosphate, whose ions $\mathrm{PO}_{4}^{3-}$ and $\mathrm{HPO}_{4}^{2-}$ can precipitate. The measured orthophosphate (OP, in $\mathrm{mg} \mathrm{PO}_{4}-\mathrm{P} / \mathrm{\ell}$ ) is the total orthophosphate species (Ps or $\mathrm{Pt} \mathrm{mol} / \ell=\mathrm{mg} \mathrm{P} / \ell$ divided by 31$)$, i.e.:

$$
P_{T}=\left[\mathrm{H}_{3} \mathrm{PO}_{4}\right]+\left[\mathrm{H}_{2} \mathrm{PO}_{4}^{-}\right]+\left[\mathrm{HPO}_{4}^{2-}\right]+\left[\mathrm{PO}_{4}^{3-}\right]
$$

Then from Eqs (4) and (5), the concentration of $\mathrm{PO}_{4}^{3-}$ is found by:

$$
\left[\mathrm{PO}_{4}^{3-}\right]=\frac{P_{T} K_{P 1}^{\prime} K_{P 2}^{\prime} K_{P 3}^{\prime}}{\left(\mathrm{H}^{+}\right)^{3}+K_{P 1}^{\prime}\left(\mathrm{H}^{+}\right)^{2}+K_{P 1}^{\prime} K_{P 2}^{\prime}\left(\mathrm{H}^{+}\right)+K_{P 1}^{\prime} K_{P 2}^{\prime} K_{P 3}^{\prime}} \mathrm{mol} / \mathrm{\ell}
$$

Using Eq. (6) to calculate in terms of $\mathrm{pH}$ and $p K^{\prime}$ :

$$
\left[\mathrm{PO}_{4}^{3-}\right]=\frac{P_{T} 10^{-\left(p K^{\prime} p 1+p K^{\prime} p 2+p K^{\prime} p 3\right)}}{10^{-3 p H}+10^{-\left(p K^{\prime} p 1+2 p H\right)}+10^{-\left(p K^{\prime} p 1+p K^{\prime} p 2+p K^{\prime} p 3\right)}} \mathrm{mol} / \ell
$$

Therefore, with a known $P_{\mathrm{T}}$ and $\mathrm{pH}$, the concentration of $\mathrm{PO}_{4}^{3-}$ is found. The concentration of $\mathrm{HPO}_{4}^{3-}$ will be similarly derived.

Thus from the measured OP, $\mathrm{pH}$ and conductivity (a measure of the TDS related to ionic strength), and the equations in (1) above, the ionic products can be calculated in a given solution. For example, the ionic product of newberyite $\left(\mathrm{MgHPO}_{4}\right)$ is:

\begin{tabular}{|c|c|c|c|c|c|c|}
\hline \multicolumn{7}{|c|}{$\begin{array}{l}\text { TABLE } 4 \\
\text { Solubility products of phosphate and carbonate precipitates used to assess digester DWLs }\end{array}$} \\
\hline \multicolumn{7}{|c|}{ Solubility products used, from literature } \\
\hline $\mathrm{MgNH}_{4} \mathrm{PO}_{4}$ & $\mathrm{Ca}_{3}\left(\mathrm{PO}_{4}\right)_{2}$ & $\mathrm{MgKPO}_{4}$ & $\mathrm{MgHPO}_{4}$ & $\mathrm{Mg}_{3}\left(\mathrm{PO}_{4}\right)_{2} \cdot 8 \mathrm{H}_{2} \mathrm{O}$ & Magnesite & Calcite \\
\hline $12.36^{*}$ & $26^{\star *}$ & $10.62^{\star \star \star}$ & $5.8^{\star *}$ & $24.39^{\star \star \star *}$ & $7^{* *}$ & $6.45^{\star \star}$ \\
\hline
\end{tabular}

$$
I P=f_{d}\left[\mathrm{Mg}^{2+}\right] f_{d}\left[\mathrm{HPO}_{4}^{2-}\right]
$$

Where $p I P=-\log I P$, and the concentration of dissolved magnesium is measured in the solution (as described in methods) and $\mathrm{HPO}_{4}^{2-}$ is calculated in Eq. (7) above, using Eq. (4). This ionic product is then compared to the solubility product from literature (see Table 4) to judge if precipitation is likely to happen or not.

TABLE 4

${ }^{\star}$ Harding (2009), ${ }^{* *}$ Taylor et al. (1963), ${ }^{* *}$ Musvuto et al. (2000) 
The precipitates considered in this study are struvite (magnesium ammonium phosphate, $\mathrm{MAP}, \mathrm{MgNH}_{4} \mathrm{PO}_{4}$ ), amorphous tricalcium phosphate (ACP or TCP, $\mathrm{Ca}_{3}\left(\mathrm{PO}_{4}\right)_{2} \cdot \mathrm{xH}_{2} \mathrm{O}$ ), potassium magnesium phosphate $\left(\mathrm{KMP}, \mathrm{MgKPO}_{4}\right)$, newberyite $\left(\mathrm{MgHPO}_{4}\right)$, magnesium phosphate (bobierite, $\left.\mathrm{Mg}_{3}\left(\mathrm{PO}_{4}\right)_{2} \cdot 8 \mathrm{H}_{2} \mathrm{O}\right)$, magnesite $\mathrm{Mg}_{2}\left(\mathrm{CO}_{3}\right)_{2}$ and calcite $\mathrm{CaCO}_{3}$. Struvite $\left(\mathrm{MgNH}_{4} \mathrm{PO}_{4}\right)$ was chosen because it is a common precipitant in anaerobic DWL, as is newberyite and ACP (Musvuto et al., 2000). Bobierite was considered a possibility - however, it is said to be rare. Magnesite and calcite are possibilities at well-maintained $\mathrm{pHs}$ and high $\mathrm{Mg}$ and $\mathrm{Ca}$ concentrations. KMP (potassium magnesium phosphate, $\mathrm{MgKPO}_{4}$ ) precipitates at high $\mathrm{pH}$ and temperature (Wilsenach et al., 2007, Schuiling and Andrade, 1999), but was considered a possibility as ammonia $\left(\mathrm{NH}_{4}\right)$ that would be used for $\mathrm{NH}_{4}^{-}$struvite $\left(\mathrm{MgNH}_{4} \mathrm{PO}_{4}\right)$ precipitation is nitrified and potassium $(\mathrm{K})$ is available in ever increasing amounts due to polyphosphate release. Table 4 shows the solubility products taken from the literature that were used in this study to find precipitants.

\section{RESULTS}

The UCT NDBEPR system produced a WAS rich in $\mathrm{P}$, which is illustrated by its $\mathrm{N}$ and $\mathrm{P}$ content in Figs $2 \mathrm{a}$ and $2 \mathrm{~b}$. The $\mathrm{P}$ content of the WAS progressively increased during 2010, with a total phosphorus (TP) of about $1200 \mathrm{mg}$ P/ $\ell$ in a WAS of 6-7 g VSS/ $\ell$ during sewage batches 15 to 21 .

The two anoxic-aerobic digesters fed with this WAS have been described in some detail in previous papers. The steady state model for continuous and batch digestion was described in Mebrahtu et al. (2010), with initial results from the highTSS digester. Vogts and Ekama (2012) described the operation and testing of the NDBEPR system and linked anoxic-aerobic digesters with some results from both the high- and the lowTSS digester. This paper will present further results, with a focus on orthophosphate release and precipitation. It will also present the results of further batch tests - one on NDBEPR WAS that shows the release rate of polyphosphate from NDBEPR WAS and the other on high-TSS digester effluent sludge to observe the continued release of polyphosphate, with precipitation. Further analysis of these results with the 3-phase (aqueous-gas-solid) plant-wide, integrated biological, chemical and physical processes model of Ikumi et al. (2013) will be included in a later publication.

\section{High-TSS digester}

Precipitation of orthophosphate released from NDBEPR WAS was expected in the high-TSS digester, and indeed occurred, as is seen in the plotted calculated ionic products in Fig. 3.
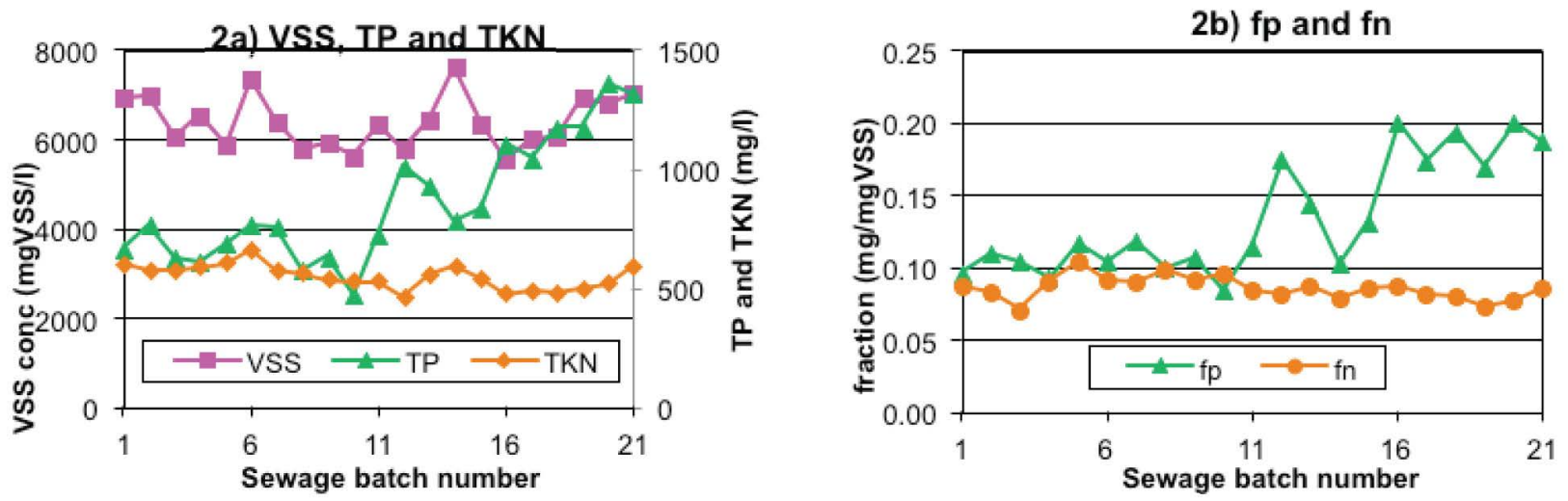

Figure 2

$N$ and $P$ content of the WAS, averaged for the duration of each sewage batch, shown by (a) VSS, TP and TKN concentrations and (b) ratios of TP ( $\left.f_{p}\right)$ and TKN (f) to VSS (for the 21 sewage batches that were fed to the NDBEPR system, numbered sequentially as horizontal axis).
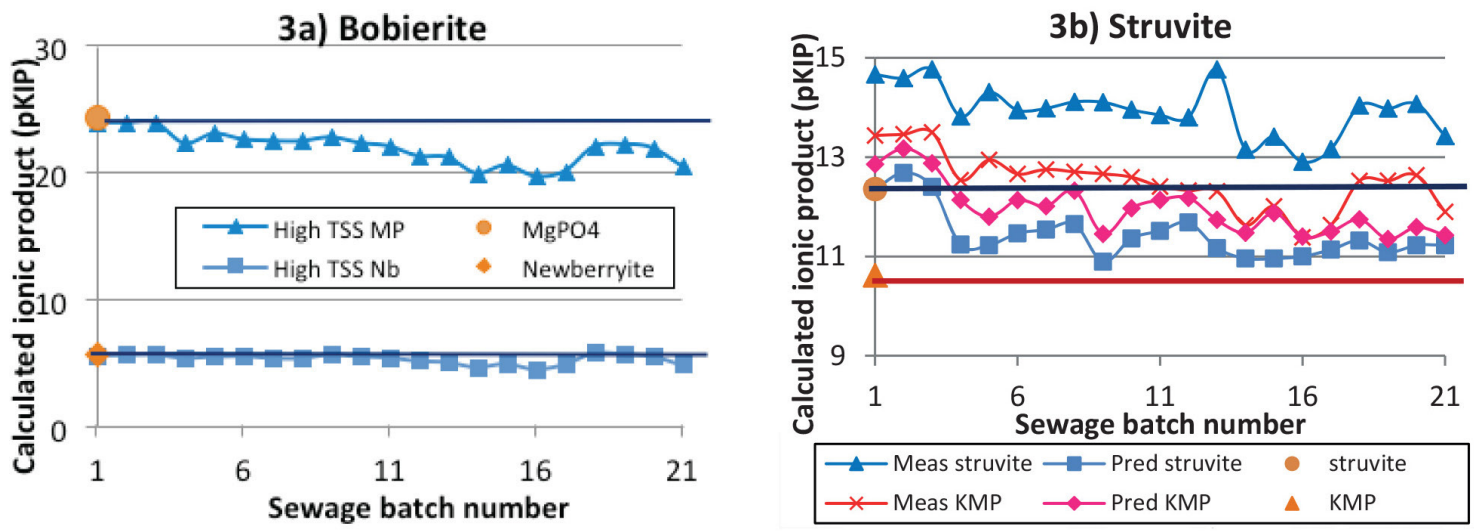

Figure 3

Ionic products (pIP) calculated for the high-TSS digester over the 2-year period of operation, averaged per sewage batch, (a) for magnesium phosphate (bobierite, $\left.\mathrm{Mg}_{3}\left(\mathrm{PO}_{4}\right)_{2} \cdot 8 \mathrm{H}_{2} \mathrm{O}\right)$ and newberyite $\left(\mathrm{MgHPO}_{4}\right)$ and $(b)$ for struvite $\left(\mathrm{MgNH}_{4} \mathrm{PO}_{4}\right)$ and $\mathrm{KMP}\left(\mathrm{MgKPO}_{4}\right)$ 
Magnesium phosphate (bobierite, $\mathrm{Mg}_{3}\left(\mathrm{PO}_{4}\right)_{2} \cdot 8 \mathrm{H}_{2} \mathrm{O}$ ) and newberyite, $\mathrm{MgHPO}_{4}$, are represented in Fig. $3 \mathrm{a}$ with a $p K_{\mathrm{sp}}$ of 24.36 and 5.8, respectively. Using measured concentrations and $\mathrm{pH}$, the ionic product ( $\mathrm{pIP}$ ) in the high-TSS digester is consistently below the $p K_{\mathrm{sp}}$ for bobierite, indicating that precipitation is/must be taking place. For newberyite, the $p I P$ hovers around the $p K_{\mathrm{sp}}$, indicating that precipitation is likely to take place. In Fig. $3 \mathrm{~b}$, struvite $\left(\mathrm{MgNH}_{4} \mathrm{PO}_{4}\right)$ is in blue with its $p K_{\mathrm{sp}}$ of 12.36 , and $\mathrm{KMP}\left(\mathrm{MgKPO}_{4}\right)$ is in red, with its $p K_{\mathrm{sp}}$ of 10.62 . The top blue line of struvite $p I P$, calculated from measured concentrations, shows that no precipitation of struvite occurred in the digester (which had complete nitrification-denitrification), although it came close during period 3 (SB 14 to 17) due to the added magnesium and also higher orthophosphate concentrations due to the high TP in the WAS. The bottom blue line of struvite $p K_{\mathrm{sp}}$ on predicted concentrations, is well below the $p K_{\mathrm{sp}}$, showing precipitation of struvite $\left(\mathrm{MgNH}_{4} \mathrm{PO}_{4}\right)$ if the ammonia had built up and not been nitrified (an unlikely situation also because the ammonia would lower from predicted concentrations due to precipitation, had it not been nitrified). For the red lines of KMP in Fig. 3b, both remain well above the $p K_{\text {sp }}$ of 10.62 , showing no precipitation of potassium with orthophosphate. This is likely to be the case, as KMP precipitates at high pHs (about 10, Wilsenach et al.,2007; Taylor et al., 1963).
Another expected precipitant is calcium phosphate $\left[\mathrm{Ca}_{3}\left(\mathrm{PO}_{4}\right)_{2}\right]$. However, calcium phosphate $p I P$ never reaches its solubility product $\left(p K_{\mathrm{sp}}\right)$, even with OP as high as $400 \mathrm{mg}$ $\mathrm{PO}_{4}-\mathrm{P} / \ell$ (SB 13 to 17 and 21 ), as seen by the orange markers in Fig. 4, well above the horizontal line of the $p K_{\mathrm{sp}}$ of 26 . But the filtered $\mathrm{Ca}^{2+}$ remains low, reaching a high of $62 \mathrm{mg} \mathrm{Ca}{ }^{2+} / \ell$ in SB 19 even when $515 \mathrm{mg} \mathrm{Ca}^{2+} / \ell$ was added to the WAS feed. This low-filtered Ca shows that Ca must precipitate, after which the magnesium phosphates dominate the stability of the solution with their ionic products.

A further possible precipitant is carbonate, with either magnesium or calcium, and therefore ionic products for magnesite $\left(\mathrm{Mg}_{2}\left(\mathrm{CO}_{3}\right)_{2}\right)$ and calcite $\left(\mathrm{CaCO}_{3}\right)$ were calculated and are shown below in Figs $5 \mathrm{a}$ and 5b, respectively. In Fig. 5a, the measured $p I P$ of magnesite is above the $p K_{\text {sp }}$ of 7 until sewage batch 13 , after which it is lower, indicating precipitation of magnesite. This can be attributed to the rise in $\mathrm{H}_{2} \mathrm{CO}_{3}{ }^{*}$ alkalinity (an indicator of buffering capacity and carbonate concentration) and filtered $\mathrm{Mg}$, the result of added hydroxide and cations ( $\mathrm{Mg}$ first, then $\mathrm{Ca}$ ) respectively, during periods 3 and 4 . In Fig. $5 b$, the $p I P$ of calcite is consistently above the $p K_{\text {sp }}$ of 6.45 , indicating no precipitation. However, the filtered $\mathrm{Ca}$ concentration remained around $10 \mathrm{mg} \mathrm{Ca}{ }^{2+} / \ell$ except when excess $\mathrm{Ca}$ was added to precipitate orthophosphate to low concentrations (20-50 $\mathrm{mg} \mathrm{PO}_{4}-\mathrm{P} / \ell$, as seen in Vogts and Ekama, 2012).

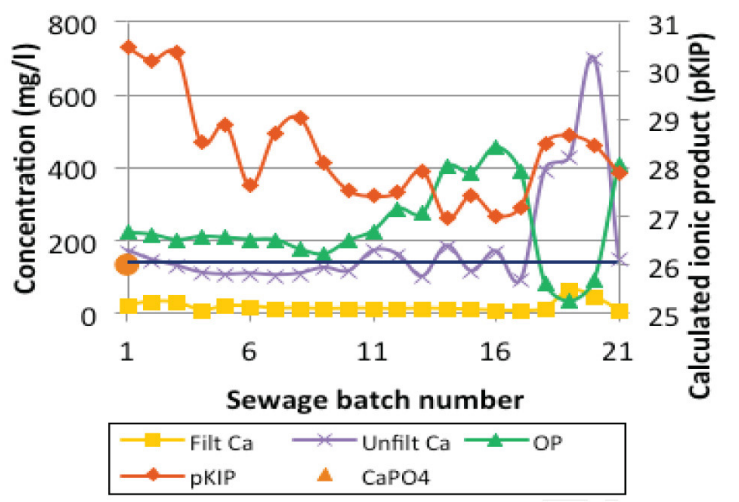

Figure 4

lonic products calculated for the high-TSS digester over the 2-year period of operation, averaged per sewage batch, for calcium phosphate $\left(\mathrm{Ca}_{3}\left(\mathrm{PO}_{4}\right)_{2}\right)$
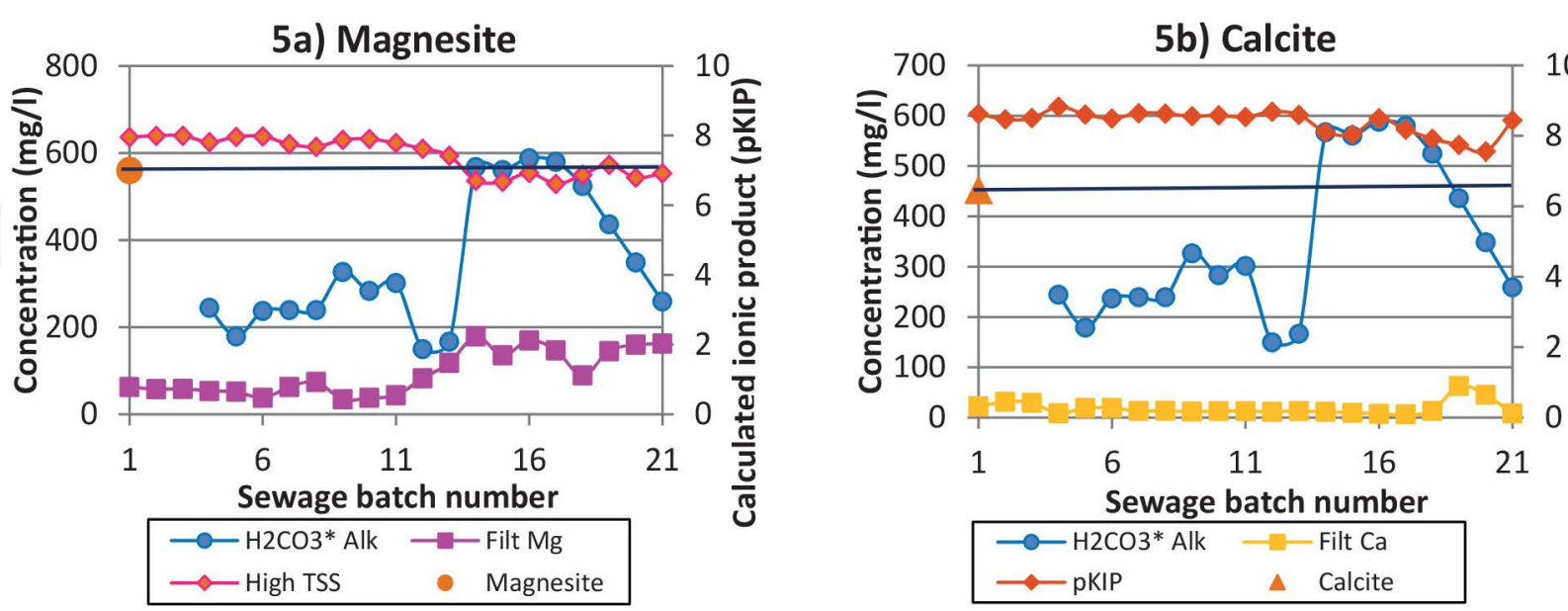

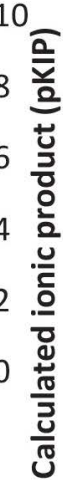

Figure 5

Ionic products calculated for the high-TSS digester over the 2-year period of operation, averaged per sewage batch, (a) for magnesite $\left(\mathrm{Mg}_{2}\left(\mathrm{CO}_{3}\right)_{2}\right)$ and (b) for calcite $\left(\mathrm{CaCO}_{3}\right)$, showing respective filtered concentrations 


\section{Low-TSS digester}

In the low-TSS digester, fed $3 \mathrm{~g}$ TSS/ $\ell$, mineral precipitation was not expected. However, as implied by Mebrahtu et al. (2008), a third of released orthophosphate will precipitate with available cations. Thus, even at such low TSS concentrations, with WAS of such a high $\mathrm{P}$ content, orthophosphate was seen to precipitate. $\mathrm{pH}$ was also a factor as precipitates were more likely at higher $\mathrm{pHs}$ due to the availability of precipitating orthophosphate anions $\mathrm{HPO}_{4}^{2-}$ and $\mathrm{PO}_{4}^{3-}$ at high $\mathrm{pH}$. This is illustrated in Table 5 with measured concentrations and calculated ionic products from 3 time periods: one at low $\mathrm{pH}$, stable $\mathrm{pH}$ and increased unfiltered TP.

Table 5 shows that the sludge had a high P content - over $200 \mathrm{mg}$ P/ $\ell$ for a WAS feed of $3 \mathrm{~g} / \ell$, and increasing throughout the testing period to a high $380 \mathrm{mg} \mathrm{P} / \ell$. The low-TSS digester had an uncontrolled low $\mathrm{pH}$ in steady-state Period 3 that resulted in no precipitation. At controlled $\mathrm{pHs}$, bobierite $\left(\mathrm{Mg}_{3}\left(\mathrm{PO}_{4}\right)_{2} \cdot 8 \mathrm{H}_{2} \mathrm{O}\right)$ precipitated, and newberyite $\left(\mathrm{MgHPO}_{4}\right)$ at higher OP and filtered magnesium (150 $\mathrm{mg} \mathrm{PO}_{4}-\mathrm{P} / \ell$ and $48 \mathrm{mg} \mathrm{Mg}^{2+} / \ell$ respectively, for steady state period 20). Struvite $\left(\mathrm{MgNH}_{4} \mathrm{PO}_{4}\right)$ is not seen to precipitate in this digester, nor magnesite $\left(\mathrm{Mg}_{2}\left(\mathrm{CO}_{3}\right)_{2}\right)$ and calcite $\left(\mathrm{CaCO}_{3}\right)$ at an $\mathrm{H}_{2} \mathrm{CO}_{3}{ }^{*}$ alkalinity range between 200 and $300 \mathrm{mg} \mathrm{CaCO} / \ell$.

Since phosphate precipitation was found in this low-TSS digester, the filtered potassium $(\mathrm{K})$ was used to track $\mathrm{P}$ release. As discussed above, $\mathrm{K}$ did not precipitate even in the high-TSS digester. Therefore, the measured and predicted filtered potassium are given in Fig. 6a. The filtered potassium is above that predicted by the model based on the $\mathrm{P}$ release at the $\mathrm{PAO}$ (and $\mathrm{OHO})$ endogenous respiration rate $\left(b_{\mathrm{G}}=0.04 / \mathrm{d}, b_{\mathrm{H}}=0.24 / \mathrm{d}\right)$.

This indicates that $\mathrm{P}$ is released by the PAOs at a rate faster than their 'death rate' at their endogenous respiration rate. Similarly the measured OP in Fig. $6 \mathrm{~b}$ also is above that predicted.

Comparing Fig. 6 a with Fig. $6 \mathrm{~b}$, a higher $\%$ of total K than $\mathrm{P}$ has been 'released' (measured as filtered), and therefore the $\mathrm{P}$ associated with the higher $\mathrm{K}$ release probably precipitated.

\begin{tabular}{|c|c|c|c|c|}
\hline \multicolumn{5}{|c|}{$\begin{array}{l}\text { TABLE } 5 \\
\begin{array}{l}\text { Measured concentrations and ionic products of precipitating orthophosphate compounds for low-TSS digester (three } \\
\text { different steady-state time periods used for examples) }\end{array}\end{array}$} \\
\hline \multirow{2}{*}{$\begin{array}{l}\text { UCT system sewage } \\
\text { bath }\end{array}$} & \multicolumn{4}{|c|}{ Measured filtered concentrations $(\mathrm{mg} / \mathrm{\ell})$ in dig } \\
\hline & $\mathbf{M g}^{2+}$ & OP & $\mathrm{Ca}^{2+}$ & $\mathbf{K}^{+}$ \\
\hline 3 & 36 & 115 & 14 & 105 \\
\hline 5 & 39 & 124 & 22 & 142 \\
\hline \multirow[t]{2}{*}{20} & 48 & 150 & 12 & 157 \\
\hline & $\mathrm{pH}$ & TP (unfilt) & TSS & VSS \\
\hline 3 & 6 & 251 & 2192 & 1485 \\
\hline 5 & 7 & 227 & 2030 & 1156 \\
\hline \multirow[t]{3}{*}{20} & 7 & 380 & 1964 & 1292 \\
\hline & \multicolumn{4}{|c|}{ Calculated ionic products } \\
\hline & $\mathrm{MgNH}_{4} \mathrm{PO}_{4}$ & $\mathrm{Ca}_{3}\left(\mathrm{PO}_{4}\right)_{2}$ & $\mathrm{MgKPO}_{4}$ & $\mathrm{MgHPO}_{4}$ \\
\hline 3 & 15.64 & 32.80 & 14.59 & 6.34 \\
\hline 5 & 14.43 & 28.33 & 13.25 & 5.94 \\
\hline 20 & 14.26 & 28.63 & 13.03 & 5.77 \\
\hline \multirow[t]{2}{*}{ Ksp } & 12.36 & 26 & 10.62 & 5.8 \\
\hline & $\mathrm{Mg}_{3}\left(\mathrm{PO}_{4}\right)_{2} \cdot 8 \mathrm{H}_{2} \mathrm{O}$ & Magnesite & Calcite & \\
\hline 3 & 26.01 & 8.49 & 9.12 & \\
\hline 5 & 23.25 & 8.23 & 8.69 & \\
\hline \multirow[t]{2}{*}{20} & 22.83 & 7.57 & 8.39 & \\
\hline & 24.39 & 7 & 6.45 & \\
\hline
\end{tabular}
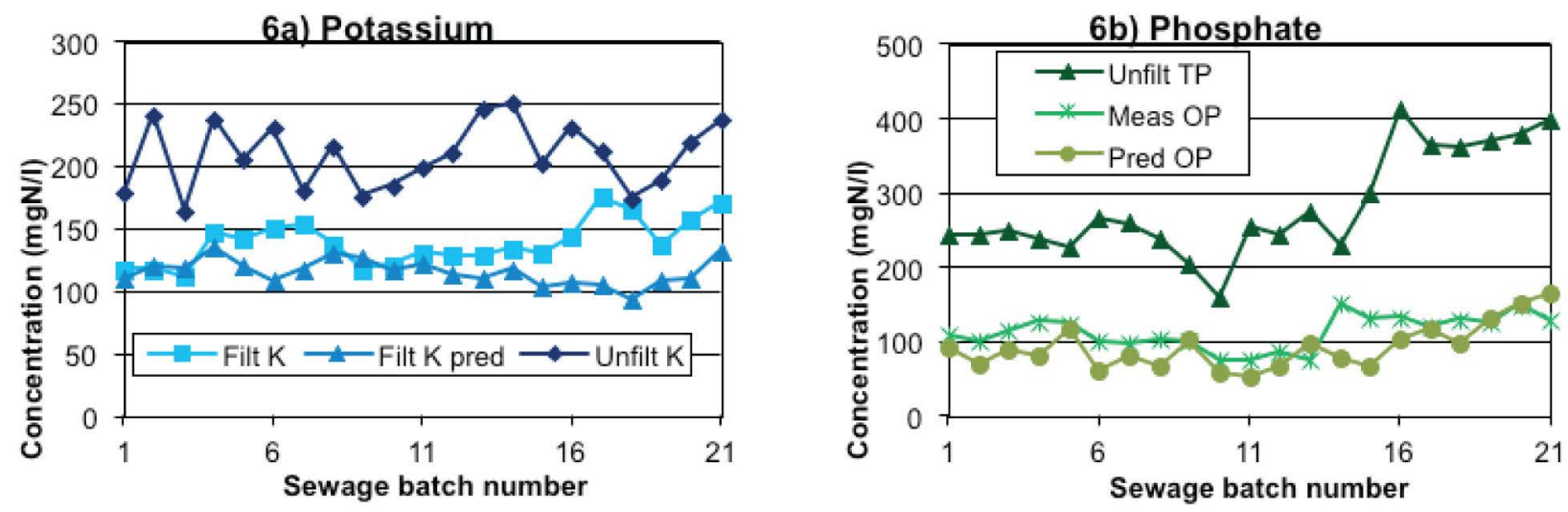

Figure 6

Low-TSS digester's (a) potassium and (b) phosphate - filtered, unfiltered and predicted filtered (polyphosphate release at rate bG) 
With precipitation occurring in even the low-TSS digester, the dilute aerobic batch tests were used to observe the release of polyphosphate without precipitation.

\section{Batch Test 2 (BT2)}

In BT2, the WAS from the NDBEPR system was batch digested at $3.0 \mathrm{~g}$ TSS/ $\ell$ (the same as that fed to the lowTSS continuous digester) to observe the rate of release of P from polyphosphate - at such a low TSS, it was believed $\mathrm{P}$ precipitation would not take place. The $\mathrm{P}$ content of the WAS was high, at $0.148 \mathrm{mg} \mathrm{P} / \mathrm{mgVSS}$. This batch test was modelled based on the activated sludge model of Ekama et al. (2006), extended for BEPR by Mebrahtu et al. (2007) according to the BEPR model of Wentzel et al. (1990). The model-predicted nitrate and VSS concentrations matched the measured concentrations well (Fig. 7), which confirmed the model $\mathrm{PAO}$ and $\mathrm{OHO}$ endogenous respiration rates $\left(b_{\mathrm{G}}=0.04 / \mathrm{d}\right.$ and $b_{\mathrm{H}}=0.24 / \mathrm{d}$ respectively). However, the predicted TSS concentration, which takes into account the changes due to polyphosphate release according to the ISS model of Ekama and Wentzel (2004), is higher and curved (Fig. 7b) compared with the linear trend observed for the measured TSS.

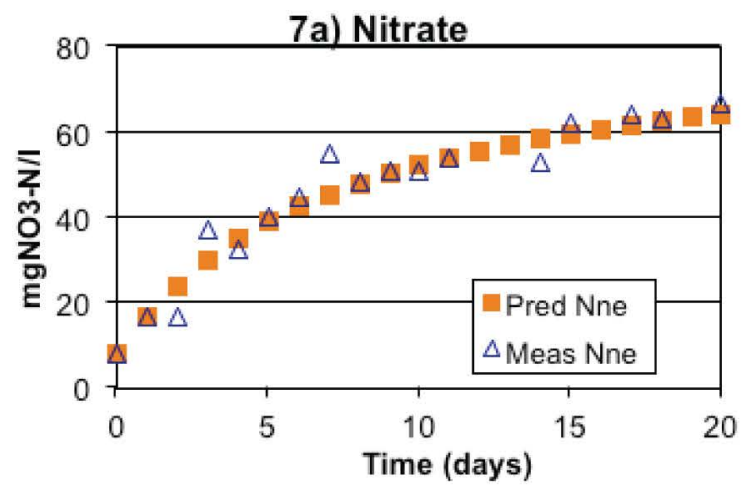

Figure 8 shows the predicted and measured $\mathrm{P}$ and $\mathrm{Mg}$, $\mathrm{Ca}$ and $\mathrm{K}$ cation release. After an initial P uptake on Day 1 (continued aerobic P uptake from the NDBEPR system), the measured $\mathrm{P}$ and $\mathrm{Mg}$ release appear linear up to Day 14, after which they show a decrease. The predicted P and Mg concentrations are curved, decreasing with time as expected from the exponential behaviour of the model. The observed rate of $\mathrm{P}$ release is $16.4 \mathrm{mg} \mathrm{PO}_{4}-\mathrm{P} /(\ell \cdot \mathrm{d})$. This observed linear release is confirmed in Fig. 9a which shows a constant daily increment in $\mathrm{P}$ concentration between 6 and $10 \mathrm{mg} \mathrm{PO}_{4}-\mathrm{P} /(\ell \cdot \mathrm{d})$. Also, while the $\mathrm{N}$ release (as $\mathrm{NH}_{4}^{+}$but nitrified to $\mathrm{NO}_{3}$ ) per cumulative oxygen consumed (Fig. 9b) is linear (as expected because the VSS removed, oxygen consumed and $\mathrm{N}$ released are proportionally related to the COD/VSS $\left(f_{\mathrm{cv}}\right)$ and N/VSS $\left(f_{\mathrm{n}}\right)$ mass ratios of the $\mathrm{OHO}$ and $\mathrm{PAO}$ biomass), the $\mathrm{P}$ release per cumulative oxygen consumed (Fig. 9b) is curved (parabolic) indicating a non-proportional P release to VSS removal. From Day 14, the measured P and cation concentrations decrease, which, though unlikely, is possibly due to dilution problems in sample analysis. More likely is that the aqueous phase had to become supersaturated to trigger nucleation of mineral seed crystals followed by mineral precipitation to saturation, even at the low initial batch VSS concentration, due to the high P content of this NDBEPR WAS.

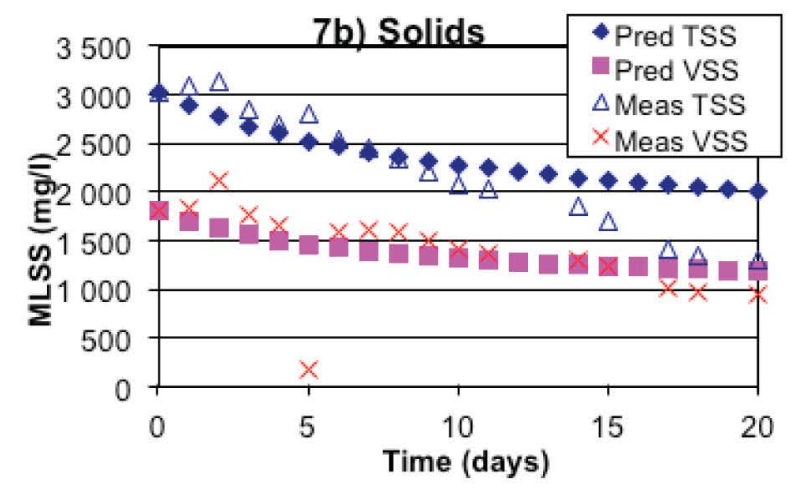

Figure 7

Measured vs predicted (a) nitrate and (b) mixed liquor solids for dilute batch on NDBEPR WAS
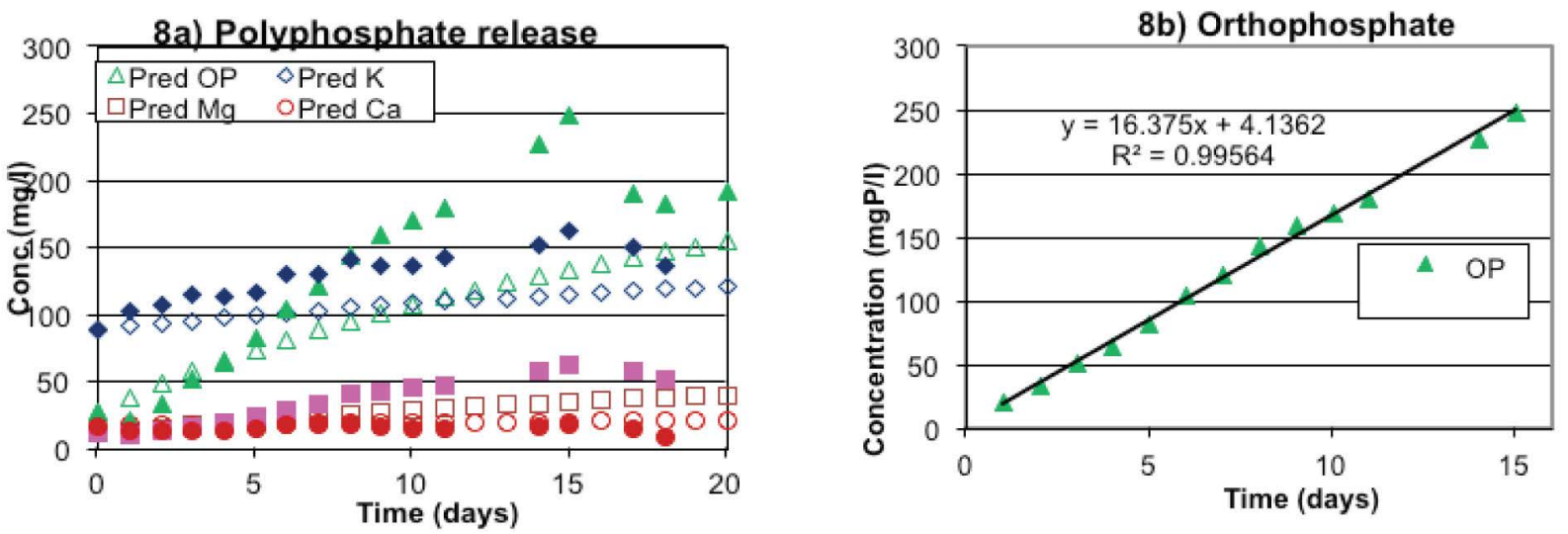

Figure 8

Polyphosphate release results of dilute batch test on NDBEPR WAS: (a) measured vs predicted orthophosphate and cations and (b) the observed linear orthophosphate with a rate of $16.375 \mathrm{mg} \mathrm{PO}_{4}-\mathrm{P} /(\ell \cdot d)$ 


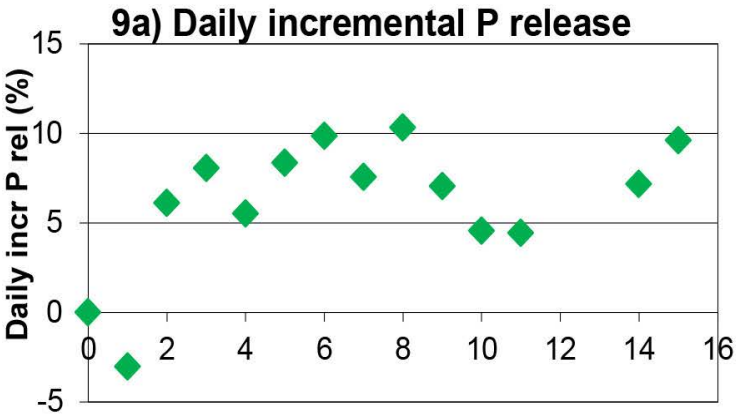

Time (days)

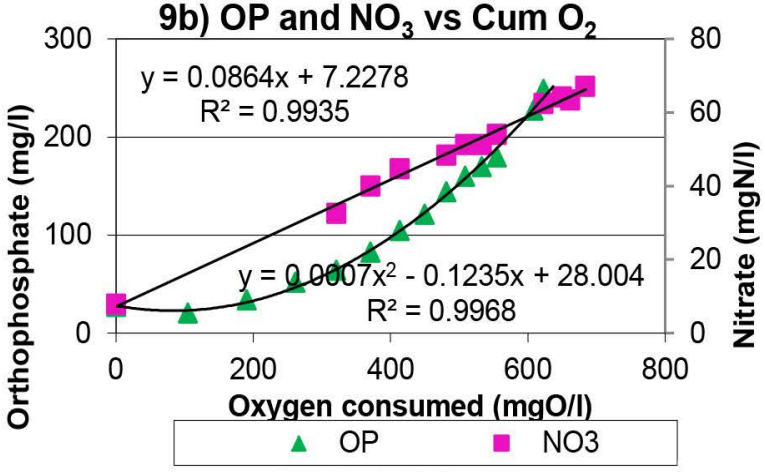

Figure 9

Polyphosphate release results of dilute batch test on NDBEPR WAS: (a) daily incremental Prelease expressed as a percentage and (b) orthophosphate and nitrate vs cumulative oxygen

The observed linear OP release in Fig. $8 \mathrm{~b}$ was then used to predict TSS concentration in the batch test. The predicted TSS now fits the measured TSS much better as shown in Fig. 10 compared with that originally predicted by the model (Fig. 7b) when the polyphosphate was released at the PAOs' endogenous respiration rate $\left(b_{\mathrm{G}}\right.$ of $\left.0.04 / \mathrm{d}\right)$.

The observed linear P release after initial P uptake was also applied to model the release of the polyphosphate cations using the observed uptake molar ratio observed in the NDBEPR system of 0.245:0.349:0.028:1 for K:Mg:Ca:P. The predicted and measured results are shown in Fig. 11a. Apart from K, which was not observed to be taken up during Day 1 of the batch test, the predicted and measured concentrations match well, confirming (i) the linear faster P release rate and (ii) that polyphosphate is released with the same cation ratio that it is taken up, in the NDBEPR system. Based on the observed linear P release rate, Fig. 11b shows with time (i) the predicted increase in aqueous $\mathrm{P}$ concentration from released polyP (PP rel), (ii) the decrease in stored $\mathrm{PAO}$ polyP (PP), (iii) the slow increase in aqueous $\mathrm{P}$ from the organically bound $\mathrm{P}$ in the $\mathrm{OHO}$ and $\mathrm{PAO}$ biomass due to endogenous respiration (other rel) and (iv) the polyP content of the PAOs (mg PP/mg PAOVSS, $f_{\mathrm{XBGPP}}$ ). The stored polyphosphate in the PAOs (PP) is depleted within 15 days and the PAO polyP

11a) Predicting PP release

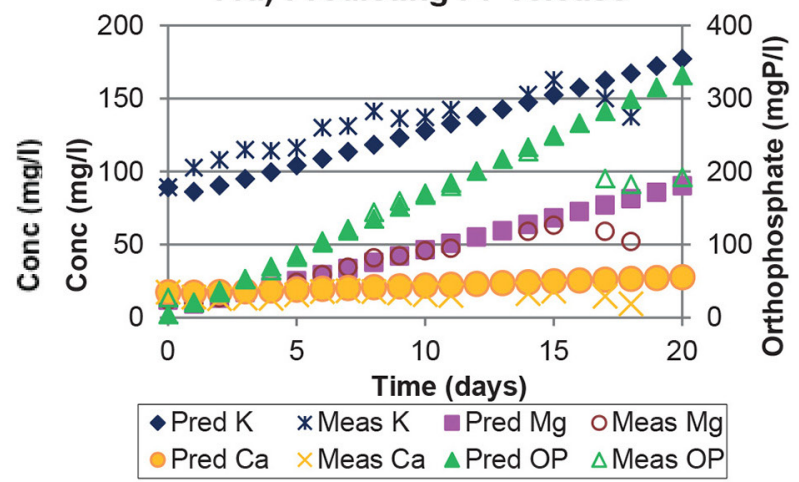

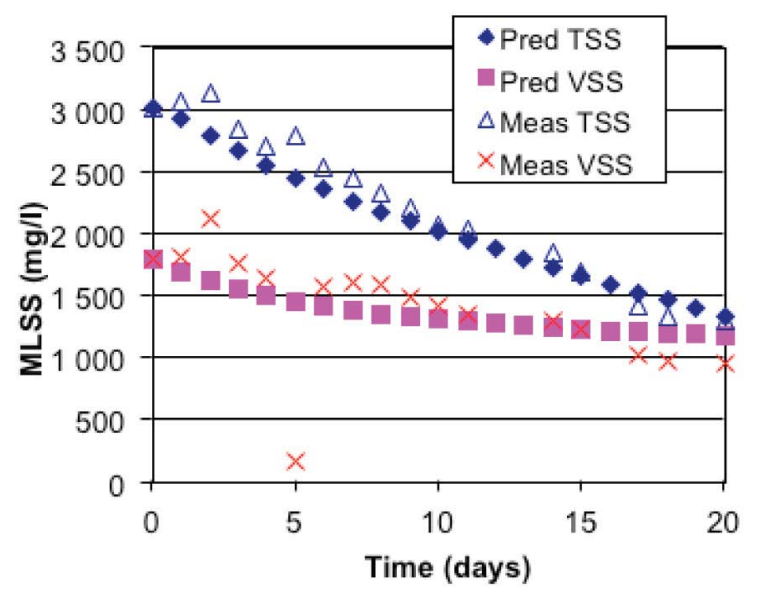

Figure 10

Improved prediction of TSS on results of dilute batch test on NDBEPR WAS, using observed linear orthophosphate release

\section{Figure 11}

Measured versus predicted polyphosphate release for dilute batch test on NDBEPR WAS, with polyphosphate released according to observed linear release (Fig. 11a, left) and the predicted P fractions (aqueous and VSS) associated with this linear release rate (Fig. 11b, right), with total phosphate of the sludge (P total). Solid fractions: remaining stored polyp (PP) and P content of PAOs $f_{X B G P}(\mathrm{mg} P / m g$ PAOVSS), biomass $P$ (other solid); aqueous fractions: polyphosphate released (PP rel), P release from biomass (other rel) 
content $\left(f_{\mathrm{XBGPP}}\right)$ decreases parabolically because the stored polyP is decreasing faster than the PAO biomass.

To check for $\mathrm{P}$ precipitation, the ionic products (as $p I P$ ) were calculated from the day-to-day measured aqueous species that make up the different minerals according to the method of Loewenthal et al. (1989). The results of these calculations for the observed polyP release in the low-TSS BT2 are shown in Table 6.

From Table 6 it can be seen that even at the low TSS concentration of $3 \mathrm{~g}$ TSS $/ \ell$, OP does appear to precipitate, due to the high $\mathrm{P}$ content of the WAS. Newberyite $\left(\mathrm{MgHPO}_{4}\right)$ and bobierite $\left(\mathrm{Mg}_{3}\left(\mathrm{PO}_{4}\right)_{2} \cdot 8 \mathrm{H}_{2} \mathrm{O}\right)$ are indicated to precipitate from around Day 8 based on measured concentrations and $\mathrm{pH}$. Other points of interest are (i) struvite $\left(\mathrm{MgNH}_{4} \mathrm{PO}_{4}\right)$ did not appear to precipitate, because in aerobic digestion the ammonia released is nitrified leaving little residual ammonia available to precipitate, (ii) potassium magnesium phosphate (KMP, $\mathrm{MgKPO}_{4}$ ) also did not appear to precipitate - it generally precipitates at higher pHs (Taylor et al., 1963, Wilsenach et al., 2007), and (iii) calcium phosphate $\left(\mathrm{Ca}_{3}\left(\mathrm{PO}_{4}\right)_{2}\right)$ did not appear to precipitate due to the low calcium content of the polyP.

\section{Revising the P release model}

Because a linear polyP release rate cannot be generalised within the endogenous respiration model framework of steady state and dynamic models, a separate first order (exponential) rate was developed for polyP release from the PAOs $\left(b_{\mathrm{GP}}\right)$, while keeping the $\mathrm{PAO}$ and $\mathrm{OHO}$ endogenous respiration rates at their usual $b_{\mathrm{G}}=0.04 / \mathrm{d}$ and $b_{\mathrm{H}}=0.24 / \mathrm{d}$ respectively to model the P release in (anoxic) aerobic digestion of BEPR WAS in general. This approach was applied not only to BT2 but also to the other batch tests at different TSS concentrations, active fraction of PAOs $\left(f_{\text {avPAO }}\right)$ and PAO P content $\left(f_{\mathrm{XBGP}}\right)$. A $b_{\mathrm{GP}}$ rate of $0.10 / \mathrm{d}$ was found, which is 2.5 times faster than the endogenous respiration rate of PAOs. The predicted and measured results for BT2 are shown in Fig. 12.
In Fig. 12a, the orthophosphate release is better predicted by the increased first-order rate of $b_{\mathrm{GP}}=0.10 / \mathrm{d}$, showing precipitation after Day 15 by a lower-than-predicted measured orthophosphate. The outliers on Days 14 and 15 can be attributed to the supersaturation required to trigger nucleation, as discussed with Fig. 8. In Fig. 12b, the potassium is well predicted without continued aerobic $\mathrm{P}$ uptake from the UCT system. Magnesium is over predicted initially until Days 14 and 15 , after which it precipitates. Filtered calcium remains low and fluctuates.

\section{Batch Test 3 (BT3)}

Waste sludge from the high-TSS 20 -d continuous anoxic-aerobic digester at $13 \mathrm{~g} \mathrm{VSS} / \ell$ was digested for a further $40 \mathrm{~d}$ in this aerobic BT3. To model this, the effluent concentrations predicted by the $20 \mathrm{~d}$ continuous steady state digester model were used as initial conditions for the $40 \mathrm{~d}$ batch test. Some polyP release was expected by this $20 \mathrm{~d}$ continuous digester waste sludge because it was fed fresh WAS from the UCT NDBEPR system daily.

The measured polyphosphate release is compared against predicted release in Fig. 13. In Fig. 13a, the digester waste (which contains a small fraction of fresh WAS, being fed daily) has a large amount of remaining stored polyphosphate, which is expected to be released, whereas in Fig. 13b, the predicted polyphosphate release is initially fast and then flattens off to lower $20 \mathrm{~d}$ predicted concentrations $\left(732 \mathrm{mg} \mathrm{PO}_{4}\right.$ $\mathrm{P} / \ell$ and $351 \mathrm{mg} \mathrm{K}^{+} / \ell$ compared to $800 \mathrm{mg} \mathrm{PO}_{4}-\mathrm{P} / \ell$ and $390 \mathrm{mg} \mathrm{K} / \ell$ in Fig. 13a). This is because, at rate $b_{\mathrm{GP}}=0.10 / \mathrm{d}$, more of the polyphosphate will have already been released in the 20-d steady-state high-TSS digester than at release rate $b_{\mathrm{G}}=0.04 / \mathrm{d}$ and therefore not appear to be released in the batch test. However, in Fig. 13, the measured concentrations appear lower than predicted, even for potassium, which remains flat.

\begin{tabular}{|c|c|c|c|c|c|}
\hline \multirow{3}{*}{ Day } & \multicolumn{5}{|c|}{$\begin{array}{c}\text { TABLE } 6 \\
\text { Calculation of ionic products for measured values batch test on dilute NDBEPR WAS }\end{array}$} \\
\hline & \multicolumn{5}{|c|}{ Product reached-measured } \\
\hline & $\mathrm{MgNH}_{4} \mathrm{PO}_{4}$ & $\mathrm{MgHPO}_{4}$ & $\mathrm{Mg}_{3}\left(\mathrm{PO}_{4}\right)_{2} \cdot 8 \mathrm{H}_{2} \mathrm{O}$ & $\mathrm{Ca}_{3}\left(\mathrm{PO}_{4}\right)_{2}$ & $\mathrm{MgKPO}_{4}$ \\
\hline $\mathbf{0}$ & 14.94 & 6.95 & 24.48 & 28.11 & 13.73 \\
\hline 1 & 15.15 & 7.15 & 24.97 & 28.69 & 13.88 \\
\hline 2 & 15.14 & 6.83 & 24.83 & 29.12 & 13.85 \\
\hline 3 & 15.02 & 6.56 & 24.48 & 29.06 & 13.71 \\
\hline 4 & 14.99 & 6.43 & 24.36 & 29.19 & 13.68 \\
\hline 5 & 15.08 & 6.30 & 24.46 & 29.55 & 13.76 \\
\hline 6 & 15.53 & 6.30 & 25.26 & 31.02 & 14.16 \\
\hline 7 & 15.30 & 6.13 & 24.74 & 30.53 & 13.93 \\
\hline 8 & 15.06 & 5.95 & 24.19 & 30.06 & 13.66 \\
\hline 9 & 14.88 & 5.86 & 23.82 & 29.62 & 13.50 \\
\hline 10 & 14.74 & 5.77 & 23.49 & 29.35 & 13.35 \\
\hline 11 & 14.55 & 5.69 & 23.09 & 28.85 & 13.14 \\
\hline 14 & 14.69 & 5.59 & 23.28 & 29.49 & 13.25 \\
\hline 15 & 14.74 & 5.56 & 23.35 & 29.65 & 13.27 \\
\hline 17 & 14.87 & 5.70 & 23.64 & 30.14 & 13.44 \\
\hline 18 & 14.14 & 5.56 & 22.24 & 28.17 & 12.75 \\
\hline$p K s p$ & 12.36 & 5.8 & 24.39 & 26 & 10.62 \\
\hline
\end{tabular}



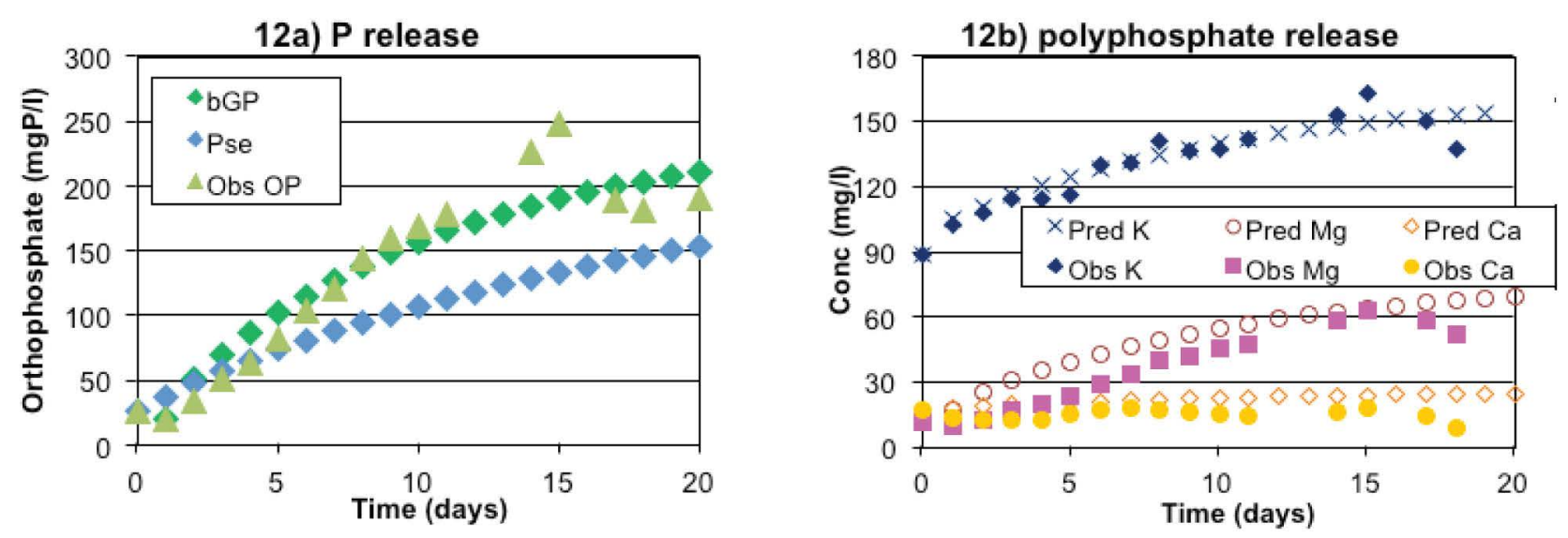

Figure 12

The observed and predicted polyphosphate release for low-TSS BT2, the measured (Obs OP) and predicted aqueous OP concentrations at the normal $P A O$ endogenous respiration rate (Pse) and the increased first order release rate of $b_{G P}=0.10 / d$ (Fig.12a, left) and cations measured (obs) versus predicted at the increased first order release rate of $b_{G P}=0.10 / d$ (Fig.12b, right)
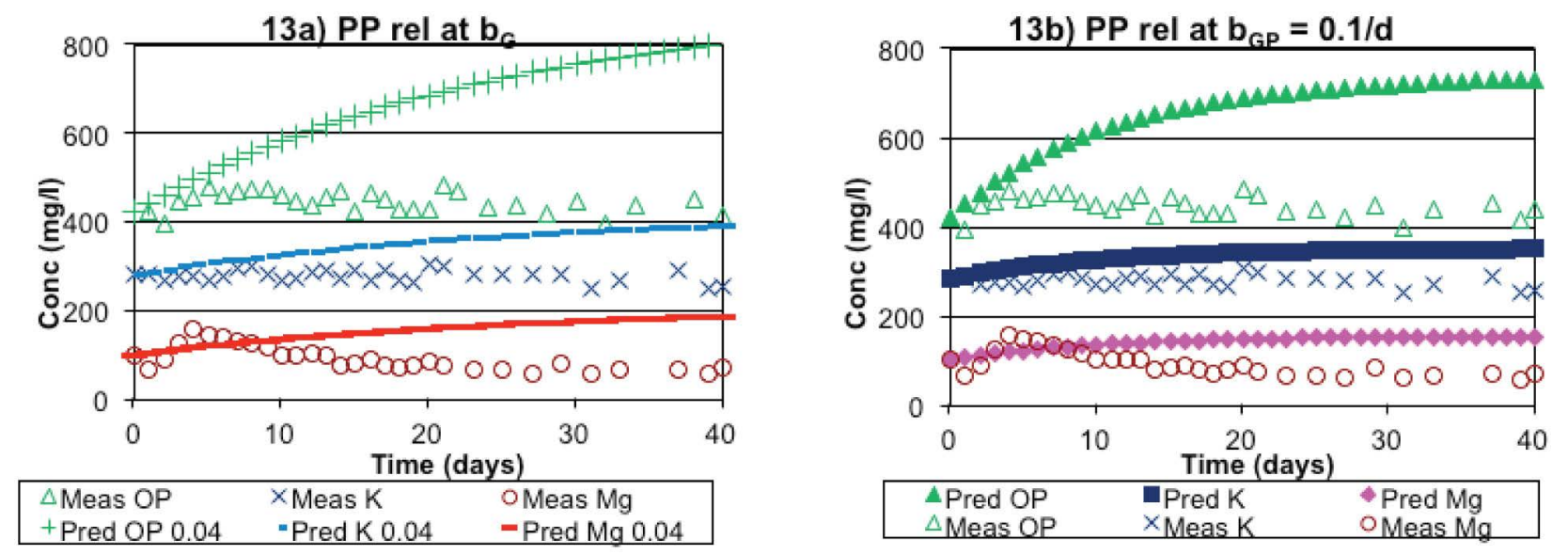

Figure 13

Measured vs. predicted polyphosphate release for BT 3 - a long-term aerobic batch test on high-TSS digester waste from an NDBEPR source system (a) at the PAO endogenous rate $b_{G}=0.04 / d$ and $(b)$ at the faster rate of $b_{G P}=0.10 / d$

In Table 7, newberyite $\left(\mathrm{MgHPO}_{4}\right)$ and bobierite

$\left(\mathrm{Mg}_{3}\left(\mathrm{PO}_{4}\right)_{2} \cdot 8 \mathrm{H}_{2} \mathrm{O}\right)$ were precipitating already in the high-TSS digester waste and continued to precipitate throughout the $40-\mathrm{d}$ aerobic batch test. Struvite $\left(\mathrm{MgNH}_{4} \mathrm{PO}_{4}\right)$ remains just above the solubility product as a result of the high orthophosphate and magnesium. Calcium phosphate $\left(\mathrm{Ca}_{3}\left(\mathrm{PO}_{4}\right)_{2}\right)$ comes close to its $K_{\text {sp }}$ by the end of the 40 days, due to a slight increase in $\mathrm{pH}$ and dissolved $\mathrm{Ca}$.

The faster polyphosphate release rate $b_{\mathrm{GP}}$ of $0.10 / \mathrm{d}$ is also applied to the high-TSS digester waste, the results of which are shown in Fig. 14 below. In Fig. 14a, the increased predicted release between rate $b_{\mathrm{G}}=0.04 / \mathrm{d}$ and rate $b_{\mathrm{GP}}=0.10 / \mathrm{d}$ is seen, with rate $\mathrm{b}_{\mathrm{GP}}$ consistently about a quarter above rate $b_{\mathrm{G}}$. The observed orthophosphate is consistently below predicted, typically half that predicted at rate $b_{\mathrm{GP}}=0.10 / \mathrm{d}$, showing the amount of $\mathrm{P}$ precipitation in the digester. Again, as in Fig. 4, low $\mathrm{OP}$ is observed in Period 4 when calcium was added to the high-TSS digester's WAS feed. In Fig. 14b, the measured filtered K follows that predicted at a polyphosphate release rate of $b_{\mathrm{G}}=0.04 / \mathrm{d}$ until sewage batch 10 , after which it follows the faster prediction of rate $b_{\mathrm{GP}}=0.10 / \mathrm{d}$ showing the usefulness of potassium as a nonprecipitating released polyphosphate cation.

Thus the high-TSS digester shows a significant amount of orthophosphate precipitation. It did show precipitation with a polyphosphate release rate bG of $0.04 / \mathrm{d}$ as was shown in Fig. 3 and Fig. 4. However, filtered potassium showed the faster polyphosphate release rate bGP of $0.10 / \mathrm{d}$.

This 40 - $\mathrm{d}$ batch test was also checked with weak acid-base chemistry calculations for precipitating minerals, some results of which are shown in Table 7 on the next page. 


\begin{tabular}{|c|c|c|c|c|c|}
\hline \multicolumn{7}{|c|}{ TABLE 7 } \\
\hline \multirow{2}{*}{ Day } & \multicolumn{5}{|c|}{ Product reached - observed } \\
\cline { 2 - 6 } & $\mathbf{M g N H}_{4} \mathbf{P O}_{4}$ & $\mathbf{M g H P O}_{4}$ & $\mathbf{M g}_{3}\left(\mathbf{P O}_{4}\right)_{2} \cdot 8 \mathrm{H}_{2} \mathbf{O}$ & $\mathrm{Ca}_{3}\left(\mathbf{P O}_{4}\right)_{2}$ & $\mathbf{M g K P O}_{4}$ \\
\hline $\mathbf{2 0}$ & 13.52 & 4.92 & 20.71 & 27.13 & 11.81 \\
\hline $\mathbf{2 5}$ & 13.53 & 4.75 & 20.57 & 27.84 & 11.85 \\
\hline $\mathbf{3 0}$ & 13.41 & 4.86 & 20.49 & 27.23 & 11.73 \\
\hline $\mathbf{3 5}$ & 13.49 & 4.92 & 20.74 & 27.15 & 11.77 \\
\hline $\mathbf{4 0}$ & 13.61 & 4.93 & 20.96 & 27.50 & 11.87 \\
\hline $\mathbf{4 5}$ & 13.61 & 5.05 & 21.08 & 27.08 & 11.90 \\
\hline $\mathbf{5 1}$ & 13.79 & 5.15 & 21.47 & 27.46 & 12.13 \\
\hline $\mathbf{5 7}$ & 13.62 & 5.02 & 21.07 & 26.89 & 11.90 \\
\hline $\mathbf{6 0}$ & 13.43 & 5.06 & 20.75 & 26.38 & 11.77 \\
\hline $\boldsymbol{K}_{\mathrm{sp}}$ & $\mathbf{1 2 . 3 6}$ & $\mathbf{5 . 8}$ & $\mathbf{2 4 . 3 9}$ & $\mathbf{2 6}$ & $\mathbf{1 0 . 6 2}$ \\
\hline
\end{tabular}
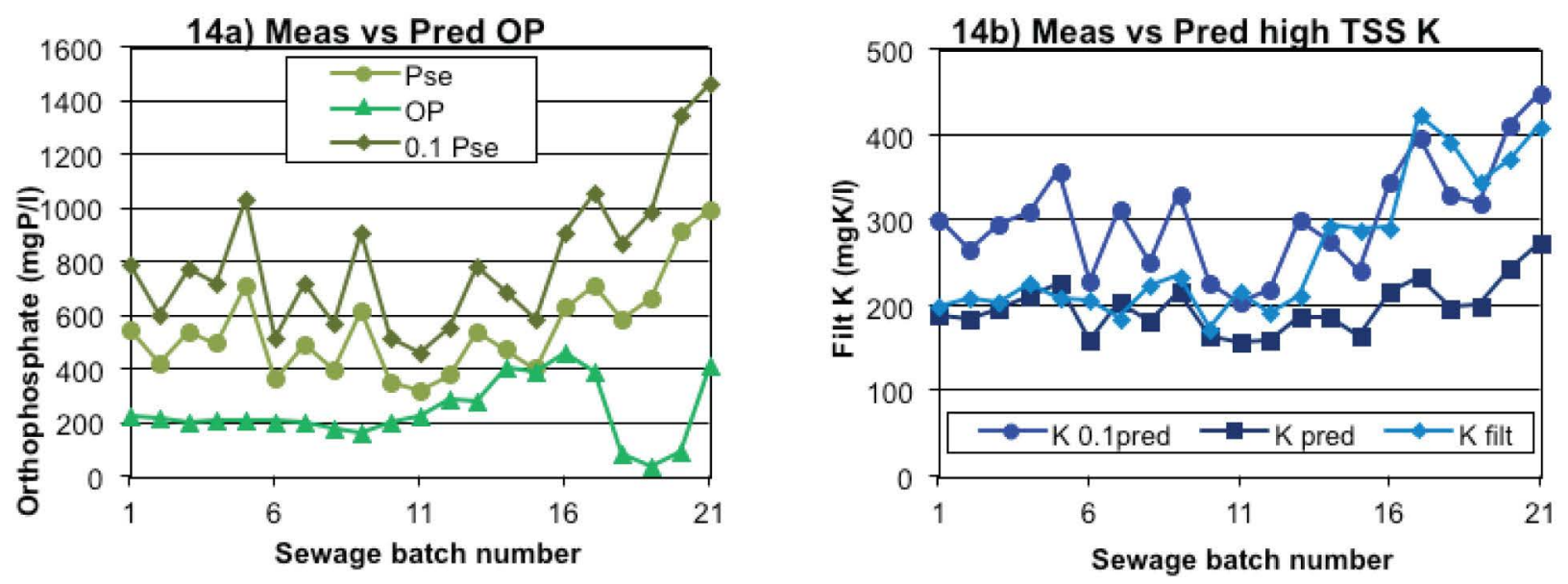

Figure 14

Fig 14a (left): High-TSS digester averaged over each of the 21 sewage batches fed to the NDBEPR source system. Measured OP vs predicted with polyphosphate release at rate $b_{G}=0.04 / d$ (Pse) and $b_{G P}=0.10 / d$ ( 0.1 Pse). Fig. $14 b$ (right): Measured filtered potassium (K filt) vs predicted with polyphosphate release at rate $b_{G}=0.04 / d$ (K pred) and $b_{G P}=0.10 / d$ (K 0.1 pred)

\section{CONCLUSIONS}

During this study of aerobic and anoxic-aerobic digestion of NDBEPR WAS, the common phosphate precipitants were newberyite $\left(\mathrm{MgHPO}_{4}\right)$ and bobierite $\left(\mathrm{Mg}_{3}\left(\mathrm{PO}_{4}\right)_{2} \cdot 8 \mathrm{H}_{2} \mathrm{O}\right)$; magnesite $\left(\mathrm{Mg}_{2}\left(\mathrm{CO}_{3}\right)_{2}\right)$ was also found to precipitate at higher magnesium concentrations, with a $\mathrm{pH}$ raised from 7.2 to 7.5. Calcium phosphate $\left(\mathrm{Ca}_{3}\left(\mathrm{PO}_{4}\right)_{2}\right)$ was not calculated to precipitate, but it obviously did precipitate as filtered $\mathrm{Ca}$ remained low, even when excess $\mathrm{Ca}$ was added to the high-TSS digester. Struvite $\left(\mathrm{MgNH}_{4} \mathrm{PO}_{4}\right)$ was not found to precipitate in either of the anoxic-aerobic digesters, nor in the aerobic batch tests, due to complete nitrification and that it generally precipitates above $\mathrm{pH}$ 8. Struvite $\left(\mathrm{MgNH}_{4} \mathrm{PO}_{4}\right)$ was not found to precipitate in this study, even if a higher $p K_{\mathrm{sp}}$ is used, such as that of 13.26 observed by Musvuto et al. (2000). Potassium was not precipitated in place of ammonia in K-struvite (KMP, $\left.\mathrm{MgKPO}_{4}\right)$, confirmed by the fact that K-struvite (KMP) generally precipitates at higher $\mathrm{pH}$ values $(>8)$ than those in the reactors of this study.

The release rate of polyphosphate from NDBEPR WAS under aerobic conditions was found to be faster than the PAO endogenous rate $b_{\mathrm{G}}$; in fact the rate was linear. For ease of modelling within the endogenous respiration model framework of steady state and dynamic models, a separate first order (exponential) rate was found for polyphosphate release, $b_{\mathrm{GP}}$ of $0.10 / \mathrm{d}$. This faster rate fitted the observed potassium release in dilute aerobic batch test BT 3 and also fitted the steady state high-TSS digester's filtered potassium, confirming not only the polyphosphate release rate, but also the usefulness of potassium as a non-precipitating cation released with polyphosphate.

\section{ACKNOWLEDGEMENTS}

This research was supported by the Water Research Commission, the National Research Foundation and the University of Cape Town.

The authors would like to acknowledge the publication workshop arranged by the South African Young Water Professionals, which the primary author attended. We would also like to convey our appreciation to the Department of Science and Technology, the Water Institute of Southern Africa and Stellenbosch University for covering the costs of the workshop. 


\section{REFERENCES}

BATSTONE DJ, AMERLINK Y, EKAMA GA, GOEL R, GRAU P, JOHNSON B, KAYA I, STEYER JP, TAIT S and TAKACS I (2012) Towards a general physicochemical framework. Water Sci. Technol. 66 (6) 1147-1161.

EKAMA GA (2010) The role and control of sludge age in biological nutrient removal activated sludge systems. Water Sci. Technol. 61 (7) $1645-1652$.

EKAMA GA and WENTZEL MC (2004) A predictive model for the reactor inorganic suspended solids concentration in activated sludge systems. Water Res. 38 (19) 4093-4106.

EKAMA GA, WENTZEL MC and SÖTEMANN SW (2006) Mass balances based plant-wide wastewater treatment plant models - Part 2: Tracking the influent inorganic suspended solids. Water SA 32 (3) 277-285.

HARDING TH (2009) A steady state stoichiometric model describing the anaerobic digestion of biological excess phosphorus removal waste activated sludge. MSc thesis, University of Cape Town, Cape Town, South Africa.

IKUMI DS, HARDING TH, BROUCKAERT CJ AND EKAMA GA (2013). Plant-wide integrated biological, chemical and physical processes modelling of wastewater treatment plants in 3 phases (aqueous-gas-solid). Research Report W138, Department of Civil Engineering. University of Cape Town, Rondebosch, 7700, Cape Town, South Africa.

LOEWENTHAL RE, EKAMA GA and MARAIS GvR (1989) Mixed weak acid-base systems - Part 1: Mixture characterization. Water SA 15 (1) 3-24.

LOEWENTHAL RE, KORNMÜLLER URC and VAN HEERDEN EP (1994) Modelling struvite precipitation in anaerobic treatment systems. Water Sci. Technol. 30 (12) 107-116.

LOEWENTHAL RE, WENTZEL MC, EKAMA GA and MARAIS GvR (1991) Mixed weak acid-base systems - Part 2: Dosing estimation, aqueous phase. Water SA 17 (2) 107-122.

MARAIS, GvR and EKAMA GA (1976) The activated sludge process Part 1 - Steady state behaviour. Water SA 2 (4) 164-199.

MEBRAHTU MK and EKAMA GA (2008) Aerobic digestion of waste activated sludge from biological nutrient removal activated sludge systems. In: WISA (Water Institute of South Africa) Biennial Conference, 18-22 May 2008, Sun City, South Africa.

MEBRAHTU MK, VOGTS M, and EKAMA GA (2010) Anoxic-aerobic digestion of waste activated sludge from biological nitrogen and phosphorus removal systems. In: WISA Biennial Conference, 18-22 April 2010, Durban, South Africa.

MEBRAHTU MK, WENTZEL MC and EKAMA GA (2007) Aerobic digestion of biological nutrient removal waste activated sludge. Research Report No W126, Dept of Civil Engineering, Univ. of Cape Town, Rondebosch, 7701, Cape, South Africa.

MUSVOTO EV, WENTZEL MC and EKAMA GA (2000) Integrated chemical-physical process modelling - II. Simulating aeration treatment of anaerobic digester supernatants. Water Res. 34 (6) 1868-1880.

RAMPHAO M, WENTZEL MC, MERRITT R, EKAMA GA, YOUNG $\mathrm{T}$ and BUCKLEY CA (2005) Impact of membrane solid-liquid separation on design of biological nutrient removal activated sludge systems. Biotechnol. Bioeng. 89 (6) 630-646.

SCHUILING RD and ANDRADE A (1999) Recovery of struvite from calf manure. Environ. Technol. 20 (7) 765-768.

TAYLOR A, GURNEY E and FRAZIER A (1963) Solubility products of magnesium ammonium and magnesium potassium phosphate. $T$. Faraday Soc. 59 (487) 1580-1584.

VOGTS M and EKAMA GA (2012) Anoxic-aerobic digestion of waste activated sludge from biological nitrogen and phosphorus removal systems. In: WISA Biennial Conference, 6-10 May 2012, Cape Town, South Africa.

VOGTS M, IKUMI DS and EKAMA GA (2014) The removal of nitrogen and phosphorus in anoxic-aerobic digestion of waste activated sludge from biological nutrient removal systems. Research Report W139, Water Research Group, Dept of Civil Eng, University of Cape Town, Rondebosch, 7700, Cape South Africa.

WENTZEL MC, EKAMA GA, DOLD PL and MARAIS GvR (1990) Biological excess phosphorus removal - steady state process design. Water SA 16 (1) 29-48.

WILSENACH JA, SCHUURBIERS CAH and VAN LOOSDRECHT MCM (2007) Phosphate and potassium recovery from source separated urine through struvite precipitation. Water Res. 41 (2) 458-466. 